\title{
Editorial: Comics Adaptations of Literary Works
}

\section{The Editors}

'(L)'hypertextualité a pour elle ce mérite spécifique de relancer constamment les œuvres anciennes dans un nouveau circuit de sens' [(h)ypertextuality has in its favour the specific merit of relaunching old works into a new circuit of meaning]. ${ }^{1}$

This edition of European Comic Art (ECA) is devoted to comics adaptations of literary works. It thereby makes a contribution to adaptation studies, a field that has rapidly expanded in tune with the postmodern awareness that we can no longer securely assign texts to individual authors as genesis and sole creative origin, even if the phenomenon of adaptation itself is not new. Gérard Genette points out that 'l'humanité, qui découvre sans cesse du sens, ne peut toujours inventer de nouvelles formes' [humanity, which keeps discovering new meanings, cannot always invent new forms]. ${ }^{2}$

There can be varying levels of transformation between a source text and its adapted version (or hypotext and hypertext, in Genette's terminology). ${ }^{3}$ Julie Sanders makes a distinction between adaptation, which 'signals an informing relationship with a source text or original' (her example is a film version of Hamlet, retaining the title) and appropriation, which 'frequently affects a more decisive journey away

1 Gérard Genette, Palimpsestes, la littérature au second degré ['Palimpsests: Literature at One Remove'] (Paris : Seuil, 1982), 558.

2 Genette, Palimpsestes, 558.

3 Adaptation theory has spawned much terminology, not all of which is common to both French- and English-speaking writers. Genette defines hypertextualité as follows: 'toute relation unissant un texte B (que j'appellerai hypertexte) à un texte antérieur A (que j'appellerai, bien sûr, hypotexte), sur lequel il se greffe d'une manière qui n'est pas celle du commentaire' [any relationship linking a text B (which I will call hypertext) to a prior text A (which I will, of course, call hypotext), onto which it grafts itself in a manner other than that of commentary]. Gérard Genette, Palimpsestes, 13. 
from the informing source into a wholly new cultural product and domain'. ${ }^{4}$ Adaptation may confirm the canonical status of its source text, whereas appropriation can be 'oppositional, even subversive'.

Adaptation theorists emphasize that their discipline is not concerned to make judgements about 'fidelity': on the contrary, as Sanders says, 'it is usually at the very point of infidelity that the most creative acts of adaptation and appropriation take place'. ${ }^{6}$ Linda Hutcheon similarly rejects 'the morally loaded discourse of fidelity'. ${ }^{7}$ However, Hutcheon also acknowledges that adapted works continue to arouse 'residual suspicion', particularly if the process involves 'lowering' a story, 'according to some imagined hierarchy of medium or genre'. ${ }^{8}$ Comics have long sat at the more disreputable end of the hierarchy. On the one hand the medium has, from its earliest days, frequently relished the opportunity to downgrade prestigious genres and canonical works of literature, from Töpffer's parodies of the improbable eventfulness of pastoral romances through to Gotlib's absurdist mock-pedagogical versions of La Fontaine's Fables in Rubrique-à-Brac. ${ }^{9}$ On the other hand, it has courted respectability by lending its mass appeal to the serious pedagogical mission of introducing children to classic novels, most famously in the 1940s, with the Classics Illustrated series in America or, at around the same time in France, René Giffey's bande dessinée versions of Balzac, Hugo and de Vigny, among others. More recently, a number of mainstream publishers in France have begun to bring out new comics versions of the literary canon: Delcourt's Ex-Libris collection, launched in 2007, for example, is built around the set texts on the school curriculum, ${ }^{10}$ and Gallimard's Fétiche collection, launched in the same year, invites comics artists to 'revisit' a work by a Gallimard author. ${ }^{11}$ Jan Baetens, while acknowledging that many excellent comics adaptations of literary texts exist (he cites Alberto Breccia's reinterpretation of Edgar Allen Poe, and Tardi's comics versions of Léo Malet thrillers), is

4 Julie Sanders, Appropriation and Adaptation (London and New York: Routledge, 2006), 26.

5 Sanders, Appropriation and Adaptation, 9.

6 Sanders, Appropriation and Adaptation, 20.

7 Linda Hutcheon, A Theory of Adaptation (New York and London: Routledge, 2006), 7.

8 Hutcheon, A Theory of Adaptation, 3.

9 See Thierry Groensteen, Parodies: La Bande dessinée au second degré (Paris: Skira Flammarion, 2010) for a comprehensive history of parody in comics.

10 Christine Gomez, 'Delcourt met les classiques en BD' [Delcourt brings out Classics in Comics Form], Livres hebdo (16 March 2007), http://www.livreshebdo.fr/actualites/ DetailsActuRub.aspx?id=596 (accessed 18 Feb 2013).

11 See the Gallimard website: http://www.bd.gallimard.fr/liste_des_ouvrages_de_la_ collection-1034-date-16.html (accessed 18 February 2013). 
pessimistic about this tendency, arguing that the adaptations that have flourished since generalist publishers discovered the 'graphic novel' are likely to suffer from '(l)a hantise de la fidelité, et, corollairement la peur de miser sur les propriétés intrinsèques de la bande dessinée' [the obsession with fidelity, and, as a corollary, the fear of relying on the intrinsic properties of comics]. ${ }^{12}$

Baetens may well be right about much of this output (although two examples, one from Delcourt and one from Gallimard, feature in the articles in this edition of ECA, and, in the case of the latter at least, the work of the artist is deemed to fall into the 'appropriative' category). Baetens's own examples indicate, though, that the relationship of comics adaptations to their literary hypotext does not have to be limited to a reverential attempt to showcase the original, in the hope that any impression made by the apparatus of panels and speech balloons will be effaced by the impact of the real cultural prize, the text. As Thierry Groensteen has said, narrative arts offer two kinds of experience: immersion in a story, but also exposure to the pleasures of a particular medium. ${ }^{13}$ Far from sacrificing these pleasures, the adapted work can seek to maximize them. An obvious and remarkable recent example of innovatory and imaginative adaptation is Winschluss's Pinocchio, a dark and in places violent re-imagining of Carlo Collodi's 1853 children's story, which also references the 1940 Disney film of the same name. The pleasures for the reader lie in the variety of graphic styles, often reminiscent of comics from the 1940s and 1950s, the deployment of page layout to run parallel and intersecting narratives, and the alternation of wordless sections, where the story is driven forward by highly effective use of the gutters, with sections featuring the commentaries of a garrulous and cynical Jiminy Cafard (the cockroach who takes the place of Collodi's Talking Cricket, Jiminy Cricket, in the Disney version). ${ }^{14}$

12 Jan Baetens, 'Le Roman graphique' [The Graphic Novel] in La Bande dessinée: Une Médiaculture ['Comics: A Media Culture'], eds Éric Maigret and Matteo Stefanelli (Paris: Armand Colin, 2012), 200-216; 208. See also another article by Baetens, in which he establishes a set of criteria (sometimes conflicting, as he points out) that have been used to assess the quality of literary comics: Jan Baetens, 'Littérature et bande dessinée: Enjeux et limites' [Literature and Comics: Issues and Limits], Cahiers de Narratologie 16 (2009), available at http://narratologie.revues.org/974 (accessed 3 January 2013).

13 Thierry Groensteen, 'Fictions sans frontières' [Fictions without Borders], in La Transécriture [Transwriting], eds André Gaudreault and Thierry Groensteen (Québec City: Nota Bene and Angoulême, Centre National de la Bande Dessinée et de l'Image, 1998), 9-29; 28.

14 Winschluss, Pinocchio (Albi: Les Requins Marteaux, 2008). 
The question of how the specific characteristics of the comics medium interact with the story content of a literary hypotext is a complex one. André Gaudreault and Philippe Marion begin their discussion of transécriture and intermédialité by asking: 'Y a-t-il vraiment moyen d'imaginer une fable dans son état de "virginité" originelle, d'avant son incarnation médiatique?' [Is there really any way to imagine a fable in its original state of 'virginity', ${ }^{15}$ before its incarnation in a medium?] ${ }^{16}$ They argue that any attempt at expression has to contend with the opacity of the medium in its materiality, whether Beethoven getting to grips with the sonority of the piano, then a new instrument, or Hergé toiling away laboriously, through multiple crossings-out, to achieve the ligne claire. ${ }^{17}$ Any medium has an intrinsic narrative potential (in the case of comics, they suggest, this would include the contiguity and succession/ transformation of images), which will interact with an extrinsic storycontent, an encounter that gives rise to creative friction. Some stories (they give the example of L'Arroseur arrosé, recounted in comics form before being filmed by the Lumière brothers) are more easily detached from the force of attraction of any one medium, ${ }^{18}$ whereas others (their example is Mathieu's comics, which dramatize the workings of the medium itself) may be unadaptable. ${ }^{19}$ The médiagénie of a narrative project is a function of how far it is dependent on its initial medium. ${ }^{20}$ Thierry Groensteen, on the other hand, argues that this is precisely the challenge for adaptation: to look for whatever a particular form does not seem capable of expressing, and to make it do just that. ${ }^{21}$

15 Gaudreault and Marion are here referring to the distinction made by Russian formalists between the underlying set of events, or 'fable', and their rearrangement (which may include omissions) for narrative purposes in the form of the syuzhet.

16 André Gaudreault and Philippe Marion, 'Transécriture et médiatique narrative: l'enjeu de l'intermédialité' [Transwriting and Narrative Mediality: the Question of Intermediality], in La Transécriture, eds Gaudreault and Groensteen, 31-52; 31.

17 Gaudreault and Marion, Transécriture, 31-38.

18 Gaudreault and Marion, Transécriture, 48-49.

19 Gaudreault and Marion, Transécriture, 52.

20 In a different article, Marion has set out to elaborate a poétique médiagénique [mediagenic poetics] for comics, arguing that two key components of its narrative potential that any expressive project will have to reckon with are graphiation, the stamp of the individual style of the artist, and heterochronia, the freeing of the time of reception of the images from determination by the medium itself, in contrast with cinema. See 'Emprise graphique et jeu de l'oie. Fragments d'une poétique de la bande dessinée' [Graphic Control and Snakes and Ladders: Fragments of a Poetics of Comics], in La Bande dessinée: Une Médiaculture, eds Maigret and Stefanelli, 175-199.

21 Groensteen, Fictions sans frontières, 29. Elsewhere, Gaudreault proposes the term adaptogénie to apply to the ease with which a narrative project can be incarnated in a number of different media. See André Gaudreault, 'Variations sur une problématique' 
Other theorists have suggested that the specific narrative potential of certain media may make them more or less apt as vehicles for adaptation. For Karin Kukkonen, it is the inherent multimodality of comics that is of particular interest to transmedial narratology, the 'project of investigating how particular media constrain as well as enable storytelling practices'. ${ }^{22}$ In comics, the functional distinction between words and images drawn up by Lessing in Laocoon, ${ }^{23}$ and taken up by later media theorists, is contradicted, since images in sequence can depict temporality, while words can become graphic elements and thus take on spatial qualities. Kukkonen then situates the question of medium specificity in relation to the historical development of the media landscape as a whole, arguing that the comic has remediated elements from earlier media in order to compensate for its shortcomings as a narrative form. ${ }^{24}$ Her example of a comics version of The Arabian Nights uses framing devices from Victorian fairy-tale books to suggest that the story is focalized through the perceptions of certain characters, and techniques from chronophotography, to give the impression of continuous movement of a character down the page. ${ }^{25}$

A consideration of the implications of a change of medium enables theorists to focus in on the affordances of comics, ${ }^{26}$ but the study of adaptation and/or appropriation also has to venture out onto what Groensteen has called the 'territoire illimite de l'intertexte' [unlimited territory of the intertext]. ${ }^{27}$ The hypertext may draw not only upon the hypotext, but also upon secondary or derived forms of it, taken, for

[Variations on a Problematic], in La Transécriture, eds Gaudreault and Groensteen, 267-271; 270.

22 Karin Kukkonen, 'Comics as a Test Case for Transmedial Narratology', SubStance 40(1) (Issue 124) (2011), 34-52; 34.

23 Gotthold Ephraim Lessing, Laocoon: An Essay on the Limits of Painting and Poetry, 1766.

24 Thierry Smolderen also rejects the notion of an ontological essence of the medium as 'sequential art' in favour of a historical approach that links it to the development of other polygraphic forms, including eighteenth-century satirical engravings, and to technologies of various kinds, including the daguerreotype and chronophotography. Smolderen is not concerned with the adaptation of individual works, however. See Thierry Smolderen, 'Histoire de la bande dessinée: Questions de méthodologie' [A History of Comics: Methodological Questions], in La Bande dessinée: Une Médiaculture, eds Maigret and Stefanelli, 71-90.

25 Kukkonen, 'Comics as a Test Case', 40-49.

26 This term was first used by James Gibson, in The Ecological Approach to Visual Perception (Boston: Houghton Mifflin, 1979). For an application to the more recent media landscape, see Gunther Kress, Literacy in the New Media Age (London: Routledge, 2003).

27 Thierry Groensteen, 'Le Processus adaptif (tentative de récapitulation raisonnée)' [The Adaptive Process (Attempt at a Reasoned Recapitulation)], in in La Transécriture, eds Gaudreault and Groensteen, 273-277; 277. 
example, from correspondence or the biography of the author. ${ }^{28}$ It may include material from previous adaptations or from other, disparate sources: Winschluss imports a Disneyesque Snow White into a subplot of Pinocchio. The new medium brings its own set of references: JeanPaul Meyer uses the term intericonicité to account for a specifically visual form of intertextuality: the incorporation of visual traces from an apparently unrelated text that can have a haunting effect. He cites Alexis Nesme's comics adaptation of Les Enfants du capitaine Grant, ${ }^{29}$ in which the depiction of an earth tremor that sends the heroes sliding down a mountain recalls the avalanche scene from Tintin au Tibet, an association that adds resonance. ${ }^{30}$ Similarly, if more directly, Winschluss's adoption of the cute Disney style for the duration of the Snow White episodes has a powerful ideological effect, evoking the saccharine and commercialized vision of childhood that his work contests. More generally, as Monique Carcaud-Macaire and Jeanne-Marie Leclerc underline, the adaptation process involves not just two terms but a third, the place where two different reference systems meet and adjust to each other. ${ }^{31}$ André Gardies refers to the 'discours implicite de la société' [implicit social discourse] and the 'ensemble de codes éthiques et idéologiques propres à une époque' [set of ethical and ideological codes belonging to a particular era]. ${ }^{32}$ The hypertext cannot help but emerge into a world where social and moral norms have evolved. What was once shocking may have become commonplace, and what was once unexceptional may now be highly offensive. The hypertext may try, through omission or modification, to render the story palatable for a new readership. Alternatively, it may take up an 'oppositional' stance, in Sanders's term,

28 Ibid.

29 Alexis Nesme, Les Enfants du capitaine Grant [Captain Grant's Children] (Paris: Delcourt, 2009).

30 Jean-Paul Meyer, 'A propos des albums de BD adaptés de romans: de la transposition littéraire à la transposition didactique'[Concerning Comics Albums Adapted from Novels: From Literary Transposition to Pedagogical Transposition], in Bande dessinée et enseignement des humanités [Comics and the Teaching of the Humanities], ed. Nicolas Rouvière, 157-170; 167.

31 '(Un) lieu d'affrontement et d'ajustement d'éléments préconstruits propres à chacun des deux objets, étant donné leurs contextes spécifiques différents' [(a) place where preconstructed elements belonging to each object meet and are adjusted, given their different specific contexts]. Monique Carcaud-Macaire and Jeanne-Marie Leclerc, 'Pour une approche sociocritique de l'adaptation cinématographique: L'Exemple de Mort à Venise' [Towards a Sociocritical Approach to Filmic Adaptation: The Example of Death in Venice], in La Transécriture, eds Gaudreault and Groensteen, 151-176; 165.

32 André Gardies, 'Le Narrateur sonne toujours deux fois' [The Narrator Always Rings Twice], in La Transécriture, eds Gaudreault and Groensteen, 65-80; 76. 
and view the material through, for example, a postcolonial or gendered lens. It may introduce material that is absent from or silenced in the original: thus where Collodi's Pinocchio visits Toyland, Winschluss's protagonist is sold to a toy factory that runs on child labour, and, a little further on, Snow White is expected to offer more than housekeeping services to the seven dwarves, who become sexual predators.

Cultural norms also evolve, not least in relation to the source text itself: a work that was once marginal or dissident, like the example of Voltaire's Candide discussed by Mathew Screech in his article here, can become a pillar of high culture. The cultural positioning of media relative to each other can also be reconfigured, although what effect the current profusion of literary adaptations will have on the standing of comics is hard to predict. They may, as Baetens fears, confirm the 'graphic novel' as a mere 'adjuvant' recruited to curb the flight from literature. ${ }^{33}$ Alternatively, they may introduce a whole new market sector to the 'intrinsic narrative potential' of the comics medium. Gaudreault asks a pertinent question: when will we see the first adaptation of a comic into literature ${ }^{34}$ As Benoît Peeters reminds us, Rodolphe Töpffer adapted one of his own graphic adventure stories into a prose version called Voyages et aventures $d u D^{r}$ Festus [Journeys and Adventures of Dr Festus] in $1840 .{ }^{35}$ Since then, the traffic has been in the other direction, although as part of convergence culture, in Henry Jenkins's term, ${ }^{36}$ the merchandising around superhero films has frequently included novelized versions of films originally based on comics. $^{37}$

It is with comics adaptations of literary texts, though, that our ECA contributors are concerned. They analyse the transformations wrought by the comics artists, which range from extreme (and, it is contended, undue) fidelity to disruption and appropriation, as well as the introduction of contemporary perspectives. Having discarded faithfulness to the subject matter of the source text as a criterion in assessing an adaptation, the authors of these essays nonetheless investigate how far the comics versions offer equivalents for the overall

33 Baetens, Le Roman graphique, 206.

34 André Gaudreault, 'Variations', 270.

35 Benoît Peeters, 'Une Exploration transmédiatique: Les Cités obscures' [A Transmedial Exploration: Cities of the Fantastic], in La Transécriture, eds Gaudreault and Groensteen, 249-263; 249-250.

36 Henry Jenkins, Convergence Culture: Where Old and New Media Collide (New York: NYU Press, 2006).

37 Wikipaedia offers a very long list: see http://en.wikipedia.org/wiki/List_of_novels_ based_on_comics (accessed 19 February 2013). 
tonality or for noteworthy formal features of the literary originals: Voltaire's irony, Conrad's ambivalence, the narratorial interventionism in Bioy Casares, the verbal agility of Queneau as he remoulds the written language to render the élan of speech.

Matthew Screech compares three different adaptations of Voltaire's Candide, first published in 1759. As Screech points out, a text which was not only ironical but subversive in its day has undergone the supreme irony of being consecrated and turned into a classroom staple. In Joann Sfar's version, the text is included in its entirety, but the scholarly impedimenta of footnotes and prefaces are replaced by marginal scribbles and scurrilous sketches with salacious speech balloons (in which Sfar occasionally picks quarrels with Voltaire, over anti-Semitism, for example). Screech argues that he thereby desacralizes the original, but also resacralizes it through a visual echo of books of hours. Sfar's version also matches Voltaire's parodic take on more respectable genres by integrating a range of borrowings from high and low culture, including many that register twenty-first-century concerns. The other two adaptations considered by Screech transpose the text more thoroughly into comics format, but are less oppositional. One of them, by Philippe Meyran, conveys irony by the simplicity of the drawings, a graphic counterpart to the deadpan tone maintained by Voltaire's narrator as the guileless characters undergo their terrible ordeals. The other, by Michel Dufranne, Gorian Depâture and Vujadin Radovanovic, in the Delcourt Ex-Libris collection, mainly dramatizes the story through striking and sumptuous images, but occasionally creates irony out of verbal/visual discrepancy. Screech notes an instance of this in relation to the unceremonious burial of Issachar the Jew. The text of the original is manipulated to heighten the impression that the unequal treatment of Jews is being denounced, thereby conferring upon it a contemporary sensibility, with the aim, perhaps, of rescuing it from accusations such as that of Sfar. More generally, Screech notes that all three adaptations update the depiction of Eldorado: the one area of the original text where idealism overcame irony, it would seem, is out of keeping with our contemporary distrust of Utopias.

Véronique Bragard's essay offers an analysis of Catherine Anyango and David Zane Mairowitz's graphic novel version of Heart of Darkness, based not only on Joseph Conrad's 1899 novella but also on his diaries, containing accounts of his own journey to the Congo. The often banal spatial and temporal indications in the diary are transposed to the comics version, giving precise locations and time frames omitted from 
the novella - in which geographical details do not in fact correspond to the real Congo riverscape - and so amounting to a more specific indictment of the Belgian colonial enterprise. Similarly, the shadowy obscurity of the images maintains the all-pervasive moral ambivalence of the original, but makes explicit graphic links between the English, Congolese and Brussels settings and, by extension, the colonial histories of the two European countries. Bragard reports that the portrayal in the comic of Marlow as having a strong resemblance to Conrad himself has been criticized by Conrad specialists who insist that biography and fiction should be kept apart. However, she argues that by intermingling them, the authors have created a mytho-biography that incorporates not only details of time and space but also material that was repressed from the diaries: the often anodyne observations from the latter are accompanied in the comic by images conveying a horror that Conrad was unable to articulate at the time, but that were explored in the imaginative world of the novella. Her claim is that the intrinsic intermediality of a medium made up of images and texts works here with the transgeneric mixture of diary and novel, ${ }^{38}$ and exposes the tension between the limited perspective of a traveller preoccupied with his own immediate concerns that is evinced in the diary, and the complex vision of the darkness at the heart of colonialism that is communicated by the novella.

Matthias Hausmann discusses the first ever comics version, by Jean Pierre Mourey, of La Invención de Morel, an oft-adapted novel published in 1940 by Adolfo Bioy Casares, in which the eponymous scientist's amazing machine produces a simulacrum of reality, making it appear that tourists are visiting a desert island, otherwise inhabited only by the narrator. Hausmann notes that the adaptation by Mourey uses comics techniques to replicate certain aspects of the original: colours render and foreground its symmetry and complicated time frames, and the panel grid is used to convey the entrapment of the characters. In addition, reflexive elements, not in the source text, such as titles visible on the books in Morel's library, allude to works by Borges, important intertexts for Bioy Casares's novel. However, Hausmann argues that the adaptation fails to render a key aspect of the original: while the comic portrays, within the diegesis, the narrator's interference with Morel's film, as he inserts himself into it, and also features emendations

38 Corresponding to what Kukkonen, after Gunther Kress, calls 'multimodality'. See Gunther Kress and Theo van Leeuwen, Reading Images: The Grammar of Visual Design (London and New York: Routledge, 1996), 177-178. 
made by the 'editor' to the narrator's manuscript (presented, as in the novel, as a found document), it fails to disturb the narrative authority of the comic itself. In this, Hausmann claims, it is inferior in its exploitation of the comics medium to Schuiten and Peeters's Les Murailles de Samaris. ${ }^{39}$ The Belgian artists' work includes clins d'œil to La Invención de Morel, but is further from it in terms of content than Mourey's comic. Nonetheless, in Hausmann's view, the shattering of the referential illusion as the walls of Samaris prove to be merely a trompe l'œil effect, is a comparable strategy to Bioy Casares's own undermining of the credibility of his narrator. Ultimately, though, Hausmann maintains that the book is designed to assert the superiority of the written word over images and so may defy transposition into a visual medium.

Armelle Blin-Rolland compares two comics versions of Raymond Queneau's Zazie dans le métro, published in 1959. The comics authors, Jacques Carelman and Clément Oubrerie, must not only take on the challenge of adapting into a verbal/visual medium a text known for its verbal innovation, but must also contend with Louis Malle's equally famous filmic adaptation from 1960 as an intertext. Like Sfar, Carelman repeats the whole of the original text: it is presented in blocks under the images, resembling the format of early twentieth-century bande dessinée. However, where the pages containing Voltaire's refined prose are defaced by Sfar's bawdy images, there is no such profanation here. Instead, Blin-Rolland claims, in this degree zero of adaptation, a concern for extreme fidelity extends beyond the hypotext to the authorial intentions of Queneau, which Carelman was at pains to ascertain, in some cases through private correspondence. In addition, a kind of visual fidelity unachievable by reference to the book alone was secured through recourse to the film version: the images of Zazie bear a strong resemblance to Malle's actress, Catherine Demongeot. Blin-Rolland argues that the comics version never attains autonomy, always weighed down by the authority of the text beneath it. Moreover, the emblematic status of many of the lines contained within speech balloons means that they do not come alive as dialogue, but stand as monuments to the great text, although she concedes that there are certain exceptions, where Carelman finds witty graphic equivalents for the words. The Oubrerie version, in contrast, has no narrative voiceover and the artist freely cuts down the dialogues to suit the comics medium, enabling

39 François Schuiten and Benoît Peeters, Les Murailles de Samaris [The Great Walls of Samaris], (Brussels: Casterman, 1983). 
characters to converse with each other, Blin-Rolland suggests, rather than quoting from pre-existing text. However, she notes that the palimpsestic presence of the Queneau text was inescapable for some critics who disapproved of the changes of tone introduced by Oubrerie's appropriative strategy.

Martha Kuhlman's essay analyses two Czech comics: Alois Nebel (2006), a trilogy by Jaroslav Rudiš and Jaromír 99, and Bomber (2007), by Jaromír 99 alone. Both have fictional protagonists, but allude to events that took place in the aftermath of the Second World War, involving the mass expulsion, and in some cases execution, of Germans from border regions of Czechoslovakia. Both therefore exemplify what Sanders calls a mode of adaptation that uses as its raw material not literary or artistic matter but the "real" matter of facts, of historical events and personalities'. ${ }^{40}$ Where the genre of historical fiction has always included background factual information as an authenticating strategy, the purpose of an author may be more radical, suggests Sanders: the desire to 'highlight gaps and absences' in previous accounts. ${ }^{41}$ This is clearly the case here: Kuhlman emphasizes that the work of these artists counters two dominant national narratives, that of flowering democracy, having thrown off the Habsburg yoke in 1918, and that of subsequent blameless victim of other tyrannical forces. In a brief resumé of the growth of an adult readership for comics once the Velvet Revolution had abolished censorship, Kuhlman stresses the influence of graphic novels from elsewhere, particularly Maus. However, she argues that, unlike Spiegelman, the two Czech authors do not foreground themselves as narrators, preferring to take up a distance to events in which they have no personal involvement. Instead, they supplement the stories of their fictional characters with factual information, in textual sections designed to appear objective. In both Czech comics, the recovery of repressed historical memories is achieved through the collapsing of time frames, enabled by the spatial resources of the comics page: in Alois Nebel, border crossings driven by different sets of tragic historical circumstances follow upon each other in a hallucination, whereas in Bomber, a house is the setting that links a recent personal tragedy to the traumatic events of the past. Curiously though, in spite of the acclaim that has greeted these comics (Alois Nebel has already generated a number of adaptations into different media), Kuhlman notes that critics have seemed blind to the thematic

40 Sanders, Adaptation and Appropriation, 138.

41 Ibid., 140. 
of the German expulsions. Her careful analytical work here is all the more valuable.

Our final essay departs from the study of adaptation altogether, focusing on the no less fascinating subject of James Gillray's 1796 print National Conveniences. John Moores argues that Gillray is not, in fact, stigmatizing the lack of hygiene of the lavatorial arrangements of the Scots, French and Dutch in contrast with the modernity of the Englishman's water closet. The satire is rather at the expense of the Englishman, whose diet of beef Moores shows to connote elitism and social divisiveness, and whose constipated state has associations not only of stagnation but of immorality. Moores also tracks the word 'convenience' through eighteenth-century discourses that associate it with expediency and hypocrisy, and goes on to find that it is JeanJacques Rousseau who unlocks the key to this print. If read not as a simple tableau pitting the Englishman against foreigners, but as a clockwise narrative, it shows a progression away from rural simplicity and towards urban degeneracy. Moreover, the Englishman's body may stand for the ill-health of the body politic in general, in which the wealthy and bloated weigh down on the lower orders. Moores supports his thesis by finding evidence of Rousseauian influence elsewhere in Gillray's work, and suggests that even in works that ostensibly support the British government's propaganda drive against the French revolutionary regime, the consistent misspelling of Rousseau's name is a tactic to dissociate the philosopher from the misrepresentation of his works by both rabid Jacobins and by conservatives. A thorough reading of Gillray's œuvre in the light of his Rousseauist leanings could, Moores suggests, shed much light on it.

In conclusion, a plea from the editors. As we go to press with this edition of $E C A$, we look back on a very successful conference of the American Bande Dessinée Society in November 2012, organized by Mark McKinney, and we look forward to the International Bande Dessinée Society Conference, to be held in June 2013, organized by Laurence Grove in collaboration with colleagues from Studies in Comics and The Journal of Comics and Graphic Novels. The quality of presentations at the first of these events, and of abstracts received in advance of the second, guarantees us a crop of outstanding submissions for ECA. At the same time, the reach of the journal beyond scholars who are able to attend these conferences is confirmed by the submissions that we are receiving from established academics and (increasingly, we are delighted to note) from postgraduates, based in institutions worldwide. 
It is therefore more important than ever for us to maximize the circulation of ECA in order to ensure the visibility and impact of the articles that we publish. The most effective way for us to achieve this is through institutional subscriptions. The setting up of this journal was a significant stage in legitimizing the study of bande dessinée and comics from other European traditions within Modern Languages departments in universities across the world. If the reputation of ECA is to grow, and with it the prestige of our discipline, we need it to be widely available in university libraries. Please help us by encouraging your librarian to take out a subscription or to renew the existing subscription: this will work to the advantage of all of us. 